\title{
SUPERVISOR'S AND TOURISM STUDENTS' EVALUATION OF WORK INTEGRATED LEARNING: A POST PLACEMENT ANALYSIS
}

\author{
Takalani RAMUKUMBA* \\ Walter Sisulu University, Department of Tourism and Hospitality Management, South Africa, e-mail : tramukumba@wsu.ac.za
}

Citation: Ramukumba, T. (2021). SUPERVISOR'S AND TOURISM STUDENTS' EVALUATION OF WORK INTEGRATED
LEARNING: A POST PLACEMENT ANALYSIS. GeoJournal of Tourism and Geosites, $35(2), \quad 390-397$.
https://doi.org/10.30892/gtg. $35217-663$

\begin{abstract}
The success of work-integrated learning (WIL) in academic activities is dependent on feedback from supervisors and the students themselves. Feedback from industry supervisors is crucial for the success of WIL activities in academic qualifications. The purpose of this paper is to analyse the evaluations of supervisors of Lerotholi Polytechnic 2019 final year tourism students WIL and the evaluation of WIL by students themselves. This was done by supervisors evaluating the freque ncy with which they observed certain behaviour from the students. The evaluation questionnaire formed part of the final WIL report that the students submitted back to the institution upon completing the WIL program. The findings of this research indicate that overall observations by supervisors were consistently and often whilst from a student's perspective, findings show that payment for WIL and gender affect aspects related to how they agreed or disagreed with statements in question.
\end{abstract}

Key words: work-integrated learning, industry supervisors, academic qualifications, tourism industry, tourism students

$* * * * * *$

\section{INTRODUCTION}

The dynamic nature of the tourism has seen the industry require skills and competencies that can serve the ever-changing demands of tourists. This has made apparent a gap between the requirements of the industry and provisions made by postschool education institutions (Zehrer and Mössenlechner, 2009). Global expectations place a demand of tourism graduates to be work-ready and possess a wide range of competencies and qualities to meet the ever-changing needs of the tourists (Yorke and Harvey, 2005). This has seen the success of academic programmes of institutions of higher learning being measured by their ability to impart on graduate's knowledge, skills and aptitude considered important by industry (Petrillose and Montgomery, 1998). This is a sentiment shared by captains of industry and professionals indicating the importance of integrating academic study and experiential education with the aim to provide students with effective opportunities for success in their chosen industry (Kay and DeVeau, 2013). Based on the above discussed views, the purpose of this paper is to analyse the evaluations of supervisors of Lerotholi Polytechnic 2019 final year tourism students WIL and the evaluation of WIL by students themselves. Central to the study was the question of how supervisors evaluate WIL and how do students themselves evaluate their own WIL experiences? The objective of the study was to establish how the supervisors assesses WIL and how students themselves evaluate their own WIL experiences such that the results can be used to enhance the implementation WIL for the benefit of both the academic institutions, students and the tourism industry. This objective was addressed using 100 supervisor's final WIL evaluation reports and student self-evaluation reports from the department of tourism management.

\section{LITERATURE REVIEW}

According to Reeders (2000) the rising diversity in the modes of vocational learning has led to the introduction and coining of the term WIL. A review of literature reveals that there are different terms used to refer to WIL and they include amongst others, experienced-based learning, professional learning cooperative education, work-based learning, practice-based learning, work placements, internships, filed work, sandwich year degrees, and job shadowing (Groenewald, 2004). In this regard, WIL is still at many times, mistaken for a simple internship or work placement. WIL, in its various forms, has existed for more than 100 years and extensive research regarding various aspects of WIL has been conducted (Groenewald and Shurink, 2013; Kay and DeVeau, 2013; Yiu and Law, 2012; Zopiatis and Theocharous, 2013). WIL is considered as the practice that combines traditional academic knowledge/formal learning with student exposure to the world-of-work in their chosen profession (Von Treuer et al., 2010). The desired outcome for WIL is to better prepare undergraduates students for when they enter into the workforce. WIL has developed into an important feature in higher education worldwide and one which is attracting significant funding for future growth and its main idea is to encourage students to have an authentic experience in the real work environment where they are able to apply skills and knowledge gained in the classroom setting (Abeysekera, 2006).

According to CHE (2011:4), WIL can be described as an umbrella term which is used to describe curricular, pedagogic and assessment practices across a series of academic disciplines that formal learning and workplace matters. The views of Yiu and Law (2012) are that students learning in the classroom should be enhanced by WIL. It is important to note that until recently, research into supervisors and tourism student's views of their own WIL experience remained scarce. However, it is worth

"Corresponding author 
mentioning that research around the relationship between theoretical education and practical experience has been done in abundance providing clarity on roles of stakeholders in WIL (Yiu and Law, 2012; Stanley, 2005; Choy and Delahaye, 2011). The same can be said about research done on the benefits of WIL (Weible, 2010; Pitout, 2009; Zopiatis and Theocharous, 2013; Rudman and Terblanche, 2012; Leslie and Richardson, 2000), research on expectations of WIL (Cannon and Arnold, 2010; Kelley-Patterson and George, 2001; Stone and McLaren, 1999; Emslie, 2009), perceptions of WIL (Petrillose and Montgomery, 1998; Lam and Ching, 2007; Ross and Elechi, 2002; Kay and DeVeau, 2013; Cho, 2006; Tse, 2010; Beggs et al., 2008) and the contribution of WIL (Walo, 2001; Zopiatis, 2007; Groenewald and Schurink, 2003). The results of all these studies can be summed-up as providing useful information about WIL in areas identified above but all these studies fall short in assessing the supervisor's assessments of WIL and students' analysis of their own WIL experience. This current study focussed on both these aspects that continue to be missing in research around WIL in the tourism industry. The above statement is supported by Taylor and Geldenhuys (2016) and Emslie (2009) who recognised that students are key stakeholders of WIL, however, they are generally talk about rather than talked with when it comes to WIL. These students continue to be treated as objects rather than active participants of the WIL process.

It is clear that if institutions of higher learning and employers are serious about improving the quality of tourism placements, then listening to and learning first hand from students is critical. This article, on the one part is written with the intention of filling the gap in literature and providing valuable feedback on student experiences in order to assist the various stakeholders of WIL and on the other part, to review the supervisor's evaluation of WIL for tourism students.

Lawson et al. (2011) noted that WIL at tertiary institutions is mostly used in a broader sense than internships or placements. This is done to ensure that WIL is able to accommodate a broad range of activities which ensure a strong emphasis and focus on industry partnerships. The same authors went further to stressed that WIL is used interchangeably with professional learning and as such this is conceptualised as "the development of professional capabilities through teaching and learning experiences and activities that integrate academic, discipline-specific and industry-referenced knowledge, skills and attitudes. The same authors went further to note that WIL should encompass industry simulation, industry practitioner delivery, industry mentoring, industry study tour, industry placement, industry competition, and industry project. In this paper, WIL is the main focus and as such, the activities under consideration involve partnership with industry stakeholders.

The views of Fleming et al., (2008) are that the global work environment requires certain skills and attributes and not only the discipline-specific skills and knowledge which students acquire at their training institutions. The same authors stressed that these skills and attributes should be supported and reinforced throughout the student's program and these should be highlighted during the workplace learning experience. It should be noted that any type of activities included in WIL, their success will only be maintained if there are practical roles of each stakeholder to maintain strong relationships with key players of WIL. With in the framework of this research, stakeholders are defined as any individual or organisation that participates in or impacts on WIL. According to Patrick et al., 2008; Shirley et al., 2006, there are normally three key participants in WIL and they are: students, lecturers and their training institutions, and employers and workplace supervisors.

Whilst previous literature may be extensive, there is very little research regarding WIL in the tourism industry in the African continent where Lesotho is located, specifically students' post-placement perspectives. Since the students are one of the main stakeholders for WIL and they are the ones provided with the opportunity, they are ideally placed to observe and experience WIL component of their learning first hand and therefore, in evaluating the effectiveness of WIL, they are the most suitably qualified to provide the judgement (Ralph et al., 2007). In support of the above, Taylor and Geldenhuys (2016) asserts that students are the most suited to pass judgement on the effectiveness of the WIL program structure and processes involved. Cho (2006), supported by Ju et al., (2007) noted that WIL is increasingly becoming an essential part of educational preparation and as such, students are demanding effective ways to gain professional skills so that they can reduce uncertainty in the educational process. Ralph et al., (2007) advancing the views of Clift and Brady (2005) noted that the studies and research done has highlighted and revealed that the voice of students who have completed WIL placements is relatively small and that policy-makers and program administrators have more often ignored these students. Wait (2014) advanced that if the purpose of WIL is limited to students gaining work experience, then it is highly possible that its effectiveness will not be realised completely. In this regard, Ralph et al., (2007) emphasised that it is necessary to evaluate and analyse students post placement WIL results in order to improve current practices since they are the only stakeholder who have a direct, daily and intimate involvement with all aspects of the teaching and learning situation.

Karlsson (2010) noted that the ability of industry supervisors to infuse theory and practice is central to the success of WIL students as this ensures exposure and facilitates exposure to original experiences. Rayner and Papakonstantinou (2015) asserts that supervisors are an important part of the WIL experience and without them it is not education, but merely an experience and they are responsible for the transfer of theory into practice whilst facilitating, reflecting and providing feedback to the students. The role of supervisors places them in a position to evaluate the student's WIL experience and provide such feedback to the institutions of higher learning so that they can improve, enhance and create a holistic WIL program.

Odora, 2011; Bilsland and Nagy, 2015; Khuong, 2016, noted that a number of studies about the necessity and importance of industry supervisor's perspectives of students that have completed WIL has been undertaken. These authors asserts that these studies explored WIL practices from countries such as Vietnam and Botswana and they noted that these studies concluded that there was lack of depth in supervisor's final evaluations of WIL tourism students. This finding has placed the current study in a position to contribute new knowledge, addressing the lack of depth highlighted above but also contribute to allowing institutions of higher learning and the profession an opportunity to address the needs of the industry and design strategies that will ensure the continuous improvement and stability of WIL through the results of this study. Milne and Caldicott (2016) conducted a study, which explored the differences in industry supervisors' ratings of student performance on 
WIL placements and the relative importance of skills. The article examined the influence of remuneration as a factor in supervisor rating scores. The conclusions found little evidence of significant differences in patterns of supervisor ratings of student performance, or in the importance attributed to skills, in either 'paid' or 'unpaid' settings (Milne and Caldicott, 2016). It is important to note here that Milne and Caldicott (2016) suggested that industry supervisors remain important to the WIL process as they are best suited and best judges of professional competency, making their assessment of students important since the reliability of students 'self-evaluation cannot be relied upon. This current study has however, included the selfevaluation by students themselves. In their study of "A baseline study of the gaps in work-integrated Tourism learning: student expectations and perceptions", Taylor and Geldenhuys (2016) found that most of the students' received payment for their WIL placement (72,5\%). The same authors (Taylor and Geldenhuys, 2016b) conducted research into the final evaluations of WIL students by their supervisors and found that unpaid students had better job understanding and were better at completing tasks than paid students, whilst most students' were satisfied with their WIL placement (86,3\%). In the same study, the authors found that $43,8 \%$ of the students found placement of WIL within the retail or wholesale sector and these students were provided with retail and wholesale industry specific training, such as Galileo and Tour Plan, and are therefore best suited to work in this sector. It is interesting to note that only $13,7 \%$ of students found WIL placement in the retail and wholesale sector. In their studies, Ahmad (2005) and Avcikurt (2003) found that the tourism industry is dominated by females especially at lower levels of management. Most of the students during WIL work in the lower level of management in the tourism industry.

In his study of WIL process in tourism training programmes in Vietnam from the perspective of academic institutions and industry, Khuong (2016) found that the links between institutions and industry were at best superficial and unstable though there were existence of WIL initiatives. In the same vein, Bilsland and Nagy (2015) found in their study conducted on perspectives of intern work supervisors in Vietnam for Commerce and Management students from students who came from foreign university that it is important to understand supervisor's perspectives of WIL graduates. It is important to note here that capturing industry supervisor's perspectives on tourism students' performance during placement will enable academic institutions and the profession to address current needs and to design and implement strategies aimed at assuring improvement and sustainability of WIL. Tourism academic programmes came into prominence in the 1980s and they have been steadily growing since then. This is as a direct result of many governments around the world noticing the economic contribution of the sector and realised that the industry requires organisation to ensure that it meet the needs of the growing demand from tourists (Leslie and Richardson, 2000). This has propelled academic institutions to produce graduates with high quality learning, knowledge, skills and ability to meet the special needs of the tourism industry (Beggs et al., 2008; Goeldner and Ritchie, 2006; Harris and Zhao, 2004; Kok, 2000). According to Beggs et al., (2008) due to this high industry expectations, emphasis has always been placed on the need for students to acquire industry experience. The views of Tse (2010) are that many institutions of higher learning are now placing practical experience as an essential component of educational preparation for tourism graduates. The same author went further to note that these institutions of higher learning are designing academic curricula to include student work experience to complement the traditional class theory as compulsory.

The views of Fallows and Steven (2000) are that the tourism industry focusses on employing those who have proactive attitudes, capacity and capability to perceive and react to problems creatively and autonomously beyond the academic skills and knowledge they possess. Wang (2008) claimed that there is a perception that education providers are not preparing graduates adequately to meet the expectations of the industry but instead produced graduates having unrealistic expectations of an industry where operational competence is taken in high regard. This has resulted in the need to re-look into the WIL process both in vocational education and in tourism training institutions. This is to ensure that WIL is able to equip graduates with knowledge of specific disciplines, employability skills and competencies to meet the high and growing demands of the tourism industry around the world which has now become a global village (Fleming et al., 2008; Yorke, 2006).

This has seen the alignment of academic and workplace practices into qualifications aimed to be mutually beneficial for students and workplaces through a process termed Work Integrated Learning (WIL) (Nduna, 2012; South African Qualifications Authority (SAQA), 2014; Tovey, 2001). Such a process has provided a space ideal for professional development, as it occupies both learning and work (Trede, 2012). However, the success of the WIL process in its core mandate of developing workforce entry-level competencies and improving the workplace readiness of graduates (Sealey et al., 2015:53), requires the commitment of all relevant stakeholders without compromise. This process furthers requires meaningful feedback that will enable the narrowing of the gap between the current and expected performance of graduates (Peach et al., 2014), thereby allowing institutions of higher learning the ability to adapt their WIL programmes to be in line with industry requirements. Recently, it has become evident that it is difficult for students to get employment after graduation because they lack the experience and skills required to occupy advertised positions (Kim, 2014). For the tourism industry to be successful, it needs skilled, educated and well-trained workforce. The combination of learning and experience allows students to become active participants in their own education (Yiu and Law, 2012). Work Integrated Learning (WIL) demonstrates that theory reflects practice thus providing a meaningful link between what is theoretically learned in a classroom and what is practiced in the industry. This experience enables students to apply theoretical knowledge within the actual working world thereby bridging the gap between theory and practice (Zopiatis and Theocharous, 2013).

According to Karlsen (2010) supported by Sealey et al. (2015), industry supervisors main task during WIL is to integrate theory and practice as well as facilitating the exposure of the students to authentic experiences. The views of Winchester-Seeto et al. (2016) stressed the role and importance of supervisors in underpinning the success of WIL for students. Ralph et al. (2007) noted that the process of transferring theory into practice is done under the watchful eye of supervisors who provide guidance to the students and these supervisors facilitates learning and reflection but also provide feedback of the learning process to academic institutions. It can therefore be concluded that first-hand knowledge of the student's WIL experience and evaluations completed by industry supervisors are important in creating a holistic WIL programme (Rayner and Papakonstantinou, 2015). 


\section{MATERIAL AND METHODS}

This study was concerned with analysing tourism industry supervisor's assessments of Lesotho's Lerotholi Polytechnic 2019 final year tourism student's evaluation of WIL and to analysed how students themselves evaluated their own WIL experiences and to achieve this aim, the study adopted a quantitative research methodology. Bryman and Burgess (1999: 45) noted that quantitative research method is the way in which data are collected and analysed, and the type of generalisations and representations derived from the data. The objective of the study was to establish how the supervisors assesses WIL and how students themselves evaluate their own WIL experiences such that the results can be used to enhance the implementation WIL for the benefit of both the academic institutions, students and the tourism industry.

This objective was addressed using 100 supervisor's final WIL evaluation reports and student self-evaluation reports from the department of tourism management. The quantitative analysis consisted of student behaviours evaluation by the supervisors and student learning experiences evaluation by students themselves during WIL. Descriptive statistics were used to create a profile of respondents and provide insight into the evaluations of students by the supervisors and a selfevaluation by students themselves. Frequencies indicate the rating provided by supervisors for observed behaviours and students self-evaluations. T-tests were conducted to analyse statistical significant differences between certain experiences by the students and this was done to see if students evaluated their own experiences based on certain factors.

\section{RESULTS AND DISCUSSION}

The results of the study as shown in Table 1 above, reveal that the females were in majority (78\%) whilst the males only made $22 \%$. This is fair reflection since females dominate the tourism industry. These results concur with the findings of Ahmad (2005) and Avcikurt (2003) who noted that the tourism industry is dominated by females especially at lower levels of management. The results in Table 2 above show that majority of the students (74\%) did their WIL in the Hospitality sector whilst 23\% did their WIL with government sector and only $1 \%$ with the wholesale sector. The results of this study are contrary to the findings of Taylor and Geldenhuys (2016) which found that $43,8 \%$ of the students found placement of WIL within the retail or wholesale sector. These results may infer the difference of the tourism industry in African context since the study by Taylor and Geldenhuys (2016) was conducted in South Africa whilst the current study was conducted in Lesotho.

Table 1 Gender of the respondents

\begin{tabular}{|c|c|c|c|c|}
\hline \multicolumn{5}{|c|}{ Gender } \\
\hline & Frequency & Percent & Valid \% & Cumulative \% \\
\hline Male & 22 & 22 & 22 & 22 \\
\hline Female & 78 & 78 & 78 & 100 \\
\hline Total & 100 & 100 & 100 & \\
\hline
\end{tabular}

Table 2 Sub-sectors where students completed their WIL

\begin{tabular}{|c|c|c|c|c|}
\hline \multicolumn{5}{|c|}{ Under which industry sub-sector did you do your learnership? } \\
\hline & Frequency & Percent & Valid \% & Cumulative \% \\
\hline Hospitality & 74 & 74 & 74 & 74 \\
\hline Wholesale & 1 & 1 & 1 & 75 \\
\hline Government & 23 & 23 & 23 & 98 \\
\hline Retail/Services & 2 & 2 & 2 & 100 \\
\hline Total & 100 & 100 & 100 & \\
\hline
\end{tabular}

Table 3. Payment during WIL

\begin{tabular}{|c|c|c|c|c|}
\hline \multicolumn{5}{|c|}{$\begin{array}{c}\text { Did you receive payment } \\
\text { during your learnership? }\end{array}$} \\
\hline & Frequency & Percent & Valid \% & Cumulative \% \\
\hline Yes & 59 & 59 & 59 & 59 \\
\hline No & 41 & 41 & 41 & 100 \\
\hline Total & 100 & 100 & 100 & \\
\hline
\end{tabular}

Table 4. T-test for payment and experience scores

\begin{tabular}{|c|c|c|c|c|c|c|c|c|}
\hline \multirow{2}{*}{$\begin{array}{c}\text { Experience } \\
\text { score }\end{array}$} & Payment & $\mathrm{N}$ & Mean & $\begin{array}{c}\text { Std. } \\
\text { Deviation }\end{array}$ & $\mathrm{t}$ & $\mathrm{Df}$ & $\begin{array}{c}\mathrm{p}- \\
\text { value }\end{array}$ & $\begin{array}{c}\text { Cohen's } \\
\mathrm{d}\end{array}$ \\
\cline { 2 - 9 } & Yes & 59.000 & 1.536 & 0.347 & -3.685 & 98.000 & 0.000 & 0.766 \\
\cline { 2 - 9 } & No & 41.000 & 1.772 & 0.263 & -6.00 & \\
\hline
\end{tabular}

The results in Table 3 above infer that students who were paid during their WIL (59\%) were slightly higher than those who were not paid $(41 \%)$. These results again slightly differ with the findings of Taylor and Geldenhuys (2016) were they found that found that most of the students $(72.5 \%)$ received payment for their WIL placement. Once again these results maybe the influenced by the fact that the study by Taylor and Geldenhuys (2016) was conducted in South Africa, which probably has the most advanced and developed tourism industry compared to Lesotho where the current research was based. These results may also infer that due to the tourism industry size in Lesotho, which only accounted for 15.6 percent of the total economy in 2018 according to Lesotho Tourism Development Corporation (LTDC), the industry may not be in a position to pay the students since it is the requirement from the students to have the WIL component in their study to be awarded the qualification.

The tourism industry may therefore see the provision of WIL opportunities to students as a way of assisting them to obtain their academic qualification rather than seeing them as employees for them. Linking the results above under Table 3 with the results presented in Table 4, an independent-samples t-test was run to determine if there were differences in the overall experience score between students who were paid and those students who were not paid during WIL placements. Surprisingly, paid interns average experience score $(1,536+-1,772)$ was significantly lower than the unpaid intern average experience score $(1,772+-0,263), \mathrm{t}(98)=-3,685, \mathrm{p}<0.000$, Cohen's $\mathrm{d}=0766$. These findings are in line with the results of Taylor and Geldenhuys (2016) who noted that unpaid students had better job understanding and were better at completing tasks than paid students, whilst most students' were satisfied with their WIL placement (86,3\%). These findings are however, in contradiction with those of Milne and Caldicott (2016) conducted a study, which explored the differences in industry supervisors' ratings of student performance on WIL placements and the relative importance of skills with the aim to examine the influence of remuneration as a factor in supervisor rating scores. The conclusions found little evidence of significant differences in patterns of supervisor ratings of student performance, or in the importance attributed to skills, in either 'paid' or 'unpaid' settings. 


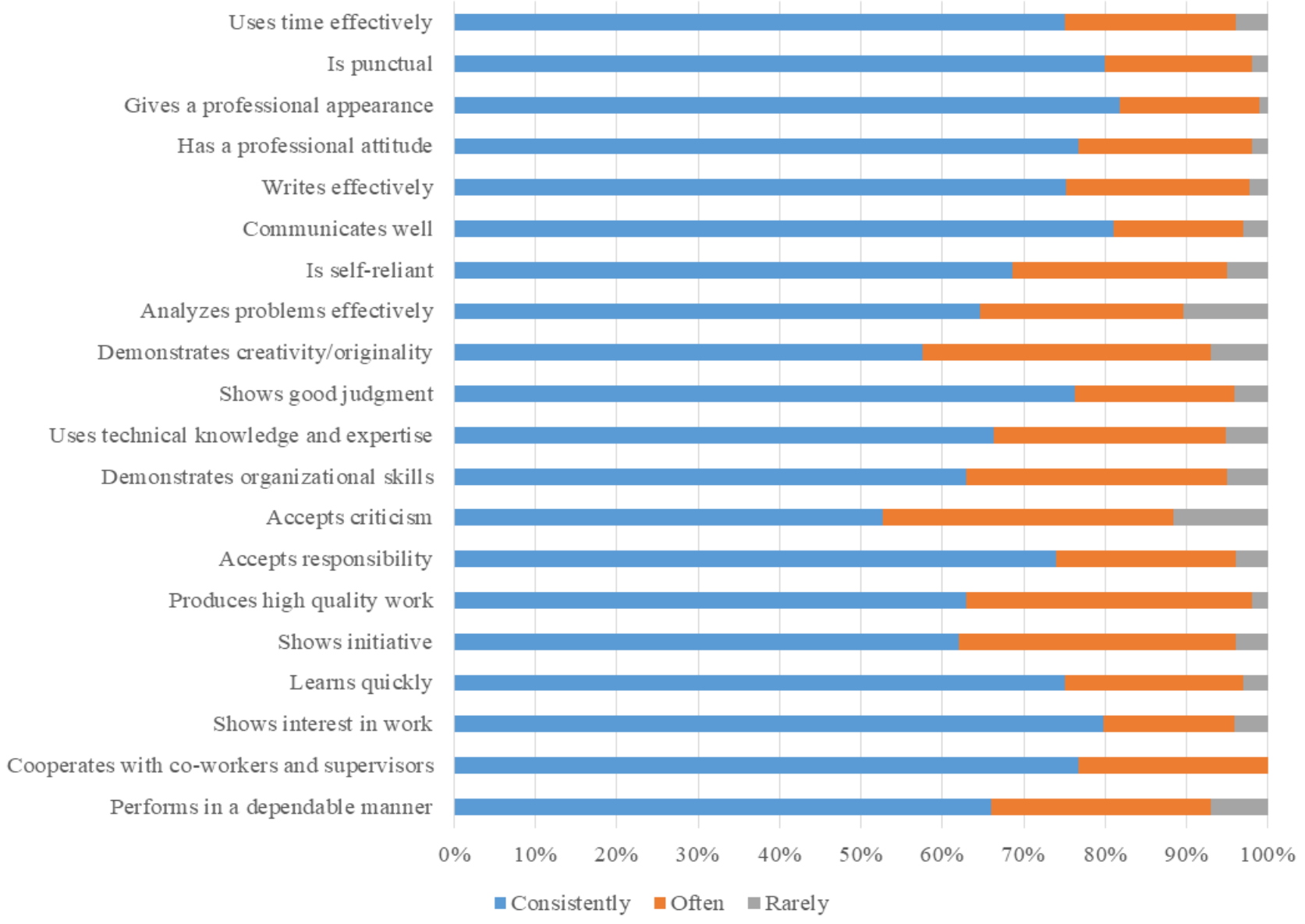

Figure 1. Rating of student behaviours during WIL by supervisors

The supervisors had to rate the students using twenty (20) different student behaviours during the WIL period and these were: performs in a dependable manner, cooperates with co-workers and supervisors, shows interest in work, learns quickly, shows initiative, produces high quality work, accepts responsibility, accepts criticism, demonstrates good organizational skills, uses technical knowledge and expertise, shows good judgment, demonstrates creativity/originality, analyses problems effectively, is self-reliant, communicates well, writes effectively, has a professional attitude, gives a professional appearance, is punctual, and uses time effectively. Figure 1 above show the results of this observation. The results of the study infer that supervisors observed these student behaviours as more consistently and often. In fact, there were only two behaviours that were rated at less than $60 \%$ and they were accepts criticism (50\%) and demonstrate creativity/originality (57\%). There were also two behaviours that supervisors rated highly than the others with both students communicates well and student gives professional appearance rated at $81 \%$. These two student behaviours ratings were slightly followed by student is punctual with a rating of $80 \%$. The rest of the student behaviours were rated between $60 \%$ and $80 \%$ respectively. Previous studies such as that of Taylor and Geldenhuys (2016), questioned the objectivity and commitment of supervisors when they rate WIL for students. Their study concluded that supervisors have a tendency of rating student behaviours during WIL as consistent and often which questions their objectivity in their ratings.

The results in Table 5 above indicate that majority of supervisors rated the performance of students during WIL as excellent (47\%) and above average (42\%) with only $10 \%$ of them rating the overall performance of the students during WIL as average (10\%). Previous studies such as that of Taylor and Geldenhuys (2016), questioned the objectivity and commitment of supervisors when they rate WIL for students. Their study concluded that supervisors have a tendency of rating student performance during WIL as excellent and above average which questions their objectivity in their ratings.

Table 5. Overall performance of the student rating by the supervisor

\begin{tabular}{|c|c|c|c|c|}
\hline \multicolumn{5}{|c|}{$\begin{array}{c}\text { Overall performance of student } \\
\text { intern (Rating by supervisor) }\end{array}$} \\
\hline & Frequency & Percent & $\begin{array}{c}\text { Valid } \\
\%\end{array}$ & $\begin{array}{c}\text { Cumulative } \\
\%\end{array}$ \\
\hline Excellent & 47 & 47 & 47 & 47 \\
\hline Above Average & 42 & 42 & 42 & 89 \\
\hline Average & 10 & 10 & 10 & 99 \\
\hline Fair & 1 & 1 & 1 & 100 \\
\hline Total & 100 & 100 & 100 & \\
\hline
\end{tabular}

Table 6 . Overall performance of the student rating by the student

\begin{tabular}{|c|c|c|c|c|}
\hline \multicolumn{5}{|c|}{$\begin{array}{c}\text { Considering your overall experience, how would you rate } \\
\text { this internship? (Rating by the student) }\end{array}$} \\
\hline & Frequency & Percent & Valid \% & Cumulative \% \\
\hline Excellent & 33 & 33 & 33 & 33 \\
\hline Very Good & 41 & 41 & 41 & 74 \\
\hline Good & 24 & 24 & 24 & 98 \\
\hline Fair & 2 & 2 & 2 & 100 \\
\hline Total & 100 & 100 & 100 & \\
\hline
\end{tabular}


The results of the study in Figure 2 above infer that majority of the students strongly agreed and agreed with the statements about their own WIL experiences with the least opinion being $71 \%$ combination on their views on "WIL provided a chance for me to use my leadership skills". This finding could be linked with the fact that when students are doing WIL, they are under guidance of the supervisor and hence they are provided with limited to non-existent opportunities to lead within the spaces they are doing their WIL. It is important to note that the highest disagreement with the statements was $17 \%$ were students indicated that they were not provided with the opportunity to use their leadership skills during WIL. Finally, and of significance is to note that there was only $1 \%$ across all statements where students strongly disagreed with a statement about their WIL experience. This is noted where $1 \%$ of the students indicated that they strongly disagreed that WIL provided them with an opportunity to apply classroom theory into practice.

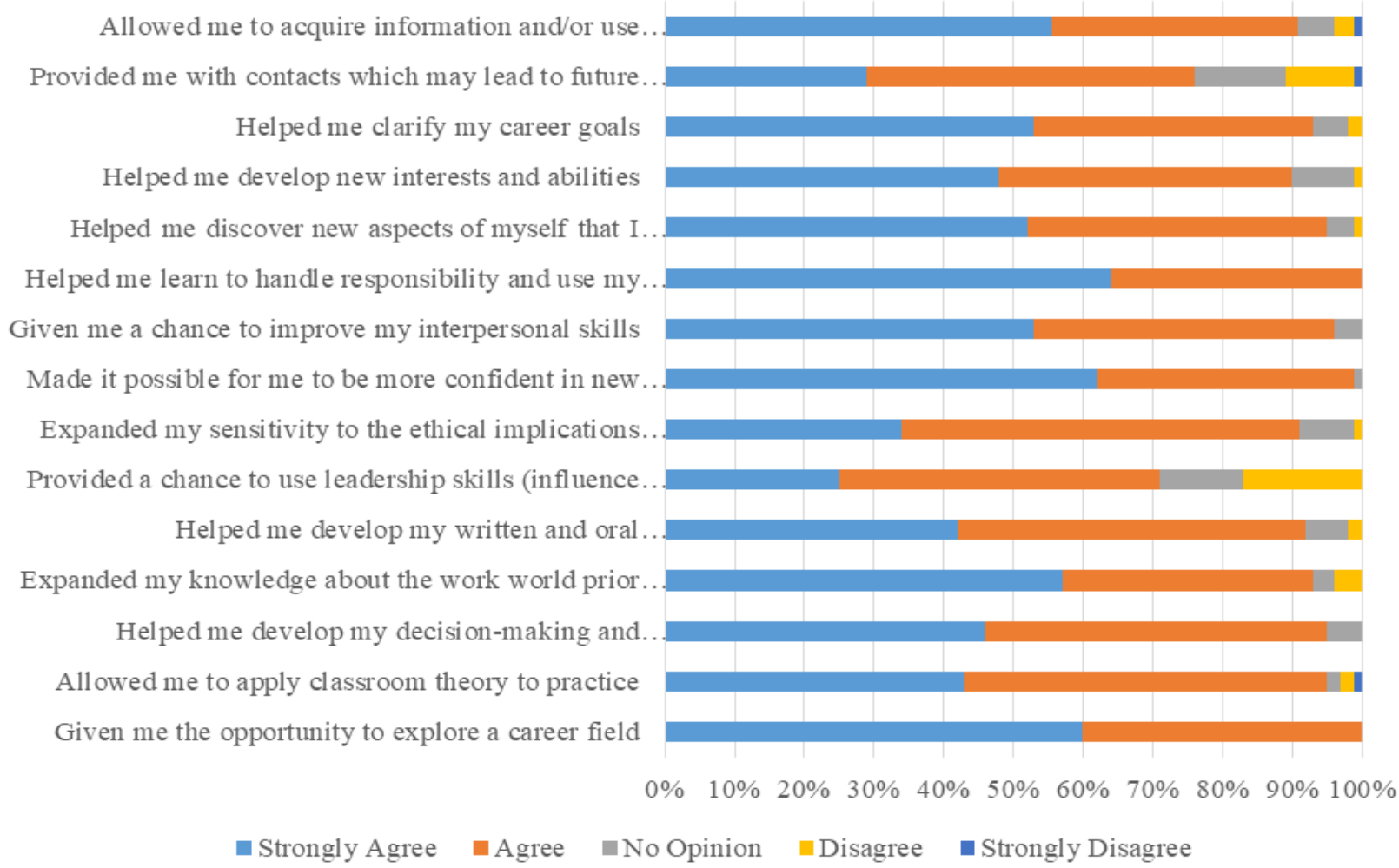

Figure 2. Rating of WIL experience by students

Table 6 results above indicate that in combination, majority of the students (74\%) rated their overall WIL experience as very good and excellent. Note is taken here that only $2 \%$ of the students rated their overall WIL experience as fair with $24 \%$ rating their overall experience as good. An independent-samples t-test was run to determine if there were differences in the overall experience of WIL rating between males and females. Males average rating of their overall experience $(1.50+-0.673)$ was significantly lower than the average female rating of overall experience $(2.08+-0.802), t(98)=-3.079, p=0.003$, Cohen's $d=0.783$.

Table 7. T-test for gender and overall WIL experience

\begin{tabular}{|l|c|c|c|c|c|c|c|c|}
\hline \multirow{2}{*}{$\begin{array}{l}\text { Rating of overall WIL } \\
\text { experience by the students }\end{array}$} & Gender & $\mathrm{N}$ & Mean & Std. Deviation & $\mathrm{t}$ & $\mathrm{df}$ & $\mathrm{p}$-value & Cohen's d \\
\cline { 2 - 10 } & Male & 22 & 1.50 & 0.673 & \multirow{2}{*}{-3.079} & \multirow{2}{*}{98} & \multirow{2}{*}{0.003} & \multirow{2}{*}{0.783} \\
\cline { 2 - 10 } & Female & 78 & 2.08 & 0.802 & & \\
\hline
\end{tabular}

\section{CONCLUSION}

While this study sheds light on the evaluation of WIL by supervisors and students, there are important limitations to the application of these findings that must be acknowledged. First, the study analysed data that centred on the evaluations of a small group of students (100) by supervisors and self-evaluation by these students themselves in one discipline only (Tourism management), that of Polytechnic University in Lesotho, a less developed country. While these data represent what is likely to be typical of supervisor and student experiences in similar regional areas, WIL placements in developed countries where consistent training opportunities for students may exist, the results could potentially be slightly different both from a supervisor and student perspectives. Additionally, these data were reflections of the supervisor's evaluation of the students during WIL and also self-reported by students through recording their own WIL experiences.

While it would be useful to triangulate data from student's self-evaluation with the perspectives of supervisor's who monitored, supported and evaluated the students WIL, these student perspectives are important because they indicate the impact of experiences on their own experiences during the WIL period.

This study results confirm the tendency of supervisors to rate student behaviours during WIL as excellent and above average. Various research articles have raised concerns regarding the gap between graduate employability skills and 
requirements of prospective employers and based on the findings of this study, as well as previous studies, it appears that supervisors complete the evaluations in a hurried fashion. It also appears that students do not evaluate themselves objectively to provide a fair assessment of their WIL experience. They normally strongly agree and agree with statements provided regarding their own experiences during WIL. Significant differences were found for payment of WIL and gender. Payment for WIL is a contentious issue and one that requires further research.

Further exploratory research into these differences may provide interesting results and can assist with the improvement of WIL placement for future tourism students. It is therefore recommended that further research be conducted into effective, model-based evaluation tools, which can be used to assess the depth of learning in the workplace.

\section{REFERENCES}

Abeysekera, I. (2006). Issues relating to designing a work-integrated learning program in an undergraduate accounting degree program and its implications for the curriculum. Asia-Pacific Journal of Cooperative Education, 7(1), 7-15.

Ahmad, G. (2005). Small firm owner-manager's networks in tourism and hospitality. International Journal of Business and Society, 4 (2), $37-55$. Avcikurt, C. (2003). Auditing managerial training needs of Turkish small and medium-sized hotel enterprise. Managerial Auditing Journal, $399-404$.

Beggs, B., Ross, C.M., \& Goodwin, B. (2008). A comparison of student and practitioner perspectives of the travel and tourism internship. Journal of Hospitality, Leisure, Sport and Tourism Education, 7(1), 31-39. https://doi.org/10.3794/johlste.71.161

Bilsland, C., \& Nagy, H. (2015). Work-Integrated Learning in Vietnam: Perspectives of Intern Work Supervisors. Asia-Pacific Journal of Cooperative Education, 16(3), 185-198.

Bryman, A., \& Burgess, R. (1999). Qualitative research. Newbury, Sage.

Cannon, J.A., \& Arnold, M.J. (1998). Student expectations of collegiate internship programs in business: a 10-year update. Journal of Education for Business, 73(4), 202-205. https://doi.org/10.1080/08832329809601630

Cho, M. (2006). Student perspectives on the quality of hotel management internships. Journal of teaching in Travel and Tourism, 6(1), 6176. https://doi.org/.org/10.1300/J172v06n01_04

Choy, S., \& Delahaye, B. (2011). Partnerships between universities and workplaces: some challenges for work-integrated learning. Studies in Continuing Education, 33(2), 157-172. https://doi.org/10.1080/0158037X.2010.546079

Clift, R., \& Brady, P. (2005). Research on methods, courses and field experiences. In Cochran-Smith, M. \& Zeichner, K., eds. Studying Teacher education: The report of the AERA panel on research and teacher education. Mahwah, NJ: American Education Research Association and Lawrence Erlbaum, 309-424.

Emslie, M. (2009). Blood, sweat and tears: Youth work students on placement and 'good WIL'. Journal of Cooperative Education \& Internships, 43(1), 65-74.

Fallows, S., \& Steven, C. (2000). Building employability skills into the higher education curriculum: A university-wide initiative. Education and Training, 42, 75-83. https://doi.org/10.1108/00400910010331620

Fleming, J., Martin, A.J., Hughes, H., \& Zinn, C. (2009). Maximizing work-integrated learning experiences through identifying graduate competencies for employability: A case study of sport studies in higher education. Asia-Pacific Journal of Cooperative Education, 10(3), $189-201$.

Goeldner, R., \& Ritchie, J.R.B. (2006). Tourism: Principles, Practices, Philosophies. $10^{\text {th }}$ edition. Hoboken, N.J.: John Wiley and Sons, Inc.

Groenewald, T. (2004), Towards a definition for cooperative education. in Coll, R.K., Eames, C., eds, International Handbook for Cooperative Education, World Association for Cooperative Education, Boston, MA, pp 17-26.

Groenewald, T., \& Schurink, W. (2003). The contribution of co-operative education in the growing talent in South Africa: a qualitative phenomenological exploration. SA Journal of Human Resource Management, 1(3), pp. 93-104.

Harris, K.J., \& Zhao, F. (2004). Industry internships: Feedback from participating faculty and industry executives. International Journal of Contemporary Hospitality Management, 16(7), 429-435. https://doi.org/10.1108/09596110410559131

Ju, J., Emenheiser, D.A., Clayton, H.R., \& Reynolds, J.S. (2007). Korean students' perceptions of the effectiveness of their internship experiences in the Hospitality industry in Korea. Asia Pacific Journal of Tourism Research, 3(1), 37-44. https://doi.org/10. $1080 / 10941665.2014 .983532$

Karlsson, L. (2010). Academic quality in internships: field supervisors' account on the value of theory in practice. The Journal of Cooperative Education and Internship, 44(2), 32-42.

Kay, C., \& DeVeau, T. (2013). A survey of lodging executives' views on internship programs and cooperatives. Journal of Hospitality and Tourism Education, 15(2), 24-29. https://doi.org/.10.1080/10963758.2003.10696765

Kelley-Patterson, D., \& George, C. (2001). Securing graduate commitment: an exploration of the competitive expectations of placement students, graduate recruits and human resource managers within hospitality, leisure and tourism industries. Hospitality Management, 20, 311-323. https://doi.org/10.1016/S0278-4319(01)00019-6

Khuong, C.T.H. (2016). Work-integrated learning process in tourism training programs in Vietnam: Voices of education and industry. AsiaPacific Journal of Cooperative Education, 17(2), 149-161.

Kim, B. (2014). Top 10 reasons why graduates can't get jobs. Access: 12.05.2020. http://briankim.net/articles/top-10-reasons-why-collegegraduates-cant-get-a-job/

Kok, R.M. (2000). Outside the box: Creating your own internship opportunities. Journal of Travel and tourism Education, 12(3), 21-23. https://doi.org/10.1080/10963758.2000.10685290

Lam, T., \& Ching, L. (2007). An exploratory study of an internship program: The case of Hong Kong students. Hospitality Management, 26, 336-351. https://doi.org/10.1016/j.ijhm.2006.01.001

Lawson, R., Fallshaw, E., Papadopoulos, T., Taylor, T., \& Zanko, M. (2011). Professional learning in the business curriculum: engaging industry, academics and students. Asian Social Science, 7 (4), 61-68. https://doi.org/10.5539/ass. v7n4p61

Leslie, D., \& Richardson, A. (2000). Tourism and cooperative education in UK undergraduate courses: are the benefits being realised? Tourism Management, 21, 489-498. https://doi.org/10.1016/S0261-5177(99)00103-X

Milne, L., \& Caldicott, J. (2016). Exploring differences in industry supervisors' ratings of student performance on WIL placements and the relative importance of skills: Does remuneration matter? Asia-Pacific Journal of Cooperative Education, 17(2), 175-187.

Nduna, N.J. (2012). The relevance of workplace learning in guiding student and curriculum development. South African Journal of Higher Education, (2), 232-248. 
Odora, R.J. (2011). Employers' perceptions regarding the quality of technical education and training in Southern Africa: A case of the Botswana technical education programme. Journal for New Generation Sciences, 9(2) 87-100.

Patrick, C.J., Peach, D., Pocknee, C., Webb, F., Fletcher, M., \& Pretto, G. (2008). The WIL (Work Integrated Learning) report: A national scoping study, Brisbane: Queensland University of Technology. Australian Learning and Teaching Council Final Report.

Pitout, B.R. (2009). Transforming work-integrated learning: strengths, shortcomings and solutions. Journal of New Generation Sciences, 7(1), 176-202.

Peach, D., Ruinard, E., \& Webb, F. (2014). Feedback on student performance in the workplace: The role of workplace supervisors. AsiaPacific Journal of Cooperative Education, Special Issue, 15(3), 241-252.

Petrillose, M.J., \& Montgomery, R. (1997). An exploratory study of internship practices in Hospitality education and industry perceptions of the importance of internships in Hospitality curriculum. Journal of Hospitality, 9(4), 46-51. https://doi.org/10.1080/10963758.1997.10685352

Ralph, E., Walker, K., \& Wimmer, R. (2007). Positive and negative aspects of the practicum: post-interns' views. Journal of Cooperative Education and Internships, 41(1), 129-142.

Rayner, G., \& Papakonstantinou, T. (2015). Student perceptions of their workplace preparedness: Making work-integrated learning more effective. Asia-Pacific Journal of Cooperative Education, 16(1), 13-24.

Reeders, E., (2000). Scholarly Practice in Work-based Learning: Fitting the glass slipper, Higher Education Research \& Development, 19:2, 205-220, https://doi.org/10.1080/072943600445655

Ross, L.E., \& Elechi, O.O. (2002). Student attitudes towards internship experiences: from theory to practice. Journal of Criminal Justice education, 13(2), 297-309. https://doi.org/10.1080/10511250200085491

Rudman, R.J., \& Terblanche, J. (2012). The perceived advantage of work experience as a learning tool for university auditing students. Southern African Journal of Accountability and Auditing Research, 13, 57-71.

Sealey, R.M., Raymond, J., Groeller, H., Rooney, K., Crabb, M., \& Watt, K. (2015). Supporting placement supervision in clinical exercise physiology. Asia-Pacific Journal of Cooperative Education, 16(1), 53-69.

Shirley, M., Davies, I., Cockburn, T., \& Carver, T. (2006). The challenge of providing work-integrated learning for law students: The QUT experience. International Journal of Clinical Legal Education, 10 (2006), 134-147.

Stanley, M. (2005). Co-operative education: An effective educational strategy. Journal for New Generation Sciences, 3(2), 105-115.

Stone, W.E., \& McLaren, J. (1999). Assessing the undergraduate intern experience. Journal of Criminal Justice Education, 10(1), 171-183. https://doi.org/10.1080/10511259900084521

Taylor, T.F., \& Geldenhuys, S. (2016a). Tourism students' post-placement opinions of work integrated learning (WIL). African Journal of Hospitality, Tourism and Leisure, 5(1), 1-11.

Taylor, T., \& Geldenhuys, S. (2016b). Tourism students' evaluation of work-integrated learning: A post-placement analysis. African Journal of Hospitality, Tourism and Leisure, 5(3) 1-13.

Taylor, T.F., \& Geldenhuys, S. (2016). A baseline study of the gaps in work-integrated Tourism learning: student expectations and perceptions. African Journal of Hospitality, Tourism and Leisure, 5(1), 1-12.

Tovey, J. (2001). Building Connections between Industry and University: Implementing an Internship Program at a Regional University, Technical Communication Quarterly, 10:2, 225-239, https://doi.org/10.1207/s15427625tcq1002_7

Trede, F. (2012). Role of work-integrated learning in developing professionalism and professional identity. Asia-Pacific Journal of Cooperative Education, 13(3), 159-167.

Tse, T.S.M. (2010). What do hospitality students find important about internships? Journal of teaching in Travel and Tourism, 10(3), 251264. https://doi.org/10.1080/15313221003792027

Von Treuer, K., Sturre, V., Keele, S., \& McLeod, J. (2010). Evaluation methodology for work integrated learning - placements. Paper presented at $3^{\text {rd }}$ Biannual ACEN National Conference, September 27-October 1, in Perth, Australia.

Wait, M. (2014). A marketing work integrated learning project: A working model. South African Journal of Higher Education, 28(5), 1680-1693.

Walo, M. (2001). Assessing the contribution of internship in developing Australian tourism and hospitality students' management competencies. Asia-Pacific Journal of Cooperative Education, 2(1), 12-28.

Wang, J. (2008). A gap analysis between tourism curriculum and industry needs \& expectations: A case of THE-ICE institutions in Australia. Master's thesis, University of Canberra, Australia.

Weible, R. (2010). Are universities reaping the available benefits internship programs offer? Journal of Education for Business, 85, 59-63. https://doi.org/10.1080/08832320903252397

Winchester-Seeto, T., Rowe, A., \& Mackaway, J. (2016). Sharing the load: Understanding the roles of academics and host supervisors in work-integrated learning, Asia-Pacafic Journal of Cooperative education, 17(2), 101-118.

Yiu, M., \& Law, R. (2012). A review of hospitality internship: Different perspectives of students, employers and educators. Journal of teaching in travel and tourism, 12, 377-402. https://doi.org/10.1080/15313220.2012.729459.

Yorke, M. (2006). Employability in higher education: what it is - what it is not. Learning and Employability Series One, ESECT and HEA, York, employability in higher education 336.pdf (accessed 9 July 2020). www.heacademy.ac.uk/assets/York/ documents/ourwork/tla/employability/id116

Yorke, E., \& Harvey, L. (2005). Embedding and integrating employability. New Directions for Institutional Research. 13-28. https://doi.org/10.1002/ir.160

Zehrer, A., \& Mössenlechner, C. (2009). Key Competencies of Tourism Graduates: The Employers' Point of View. Journal of Teaching in Travel \& Tourism. 9(3-4), 266-287. https://doi.org/10.1080/15313220903445215

Zopiatis, A. (2007). Hospitality internships in Cyprus: a genuine academic experience or a continuing frustration? International Journal of Contemporary Hospitality Management, 19(1), 66-77. https://doi.org/10.1108/09596110710724170

Zopiatis, A., \& Theocharous, A.l. (2013). Revisiting hospitality internship practices: A holistic investigation. Journal of hospitality, leisure, sport \& tourism education, 13(2013), 33-46. https://doi.org/10.1016/j.jhlste.2013.04.002

*** Council on Higher Education (CHE). (2011). Work-Integrated Learning: Good Practice Guide, Access: 13 September 2019. http://www.che.ac.za/sites/default/files/publications/Higher_Education_Monitor_12.pdf

*** South African Qualifications Authority (SAQA). (2014). Criteria for the generation and evaluation of qualifications and standards within the National Qualifications Framework, Pretoria, SA: Government Printer. 